\title{
Krzysztof Lalik, Kurdystan iracki u progu XXI wieku, Wyd. Księgarnia Akademicka, Kraków 2009, ss. 361.
}

Prace dotyczące problemu kurdyjskiego wciąż stanowią znaczącą niszę na rodzimym rynku wydawniczym, stąd pozycja autorstwa Krzysztofa Lalika jest jedną z nielicznych monografii kurdologicznych, które ukazały się w ciągu ostatniej dekady w Polsce. Autor jest absolwentem kulturoznawstwa na Uniwersytecie Jagiellońskim, gdzie obecnie pisze pracę doktorską na Wydziale Studiów Międzynarodowych i Politycznych. Od lat jest on współpracownikiem Kurdyjskiego Centrum Informacji i Dokumentacji w Krakowie. Tematyka poruszana w książce stanowi pokłosie doświadczenia nabytego w ramach pisania prac dyplomowych, jak również wyjazdów badawczych do Iraku.

Kurdystan iracki u progu XXI wieku składa się z ośmiu rozdziałów, które dopełnia thumaczenie porozumienia z 2006 roku dotyczącego aliansu partii Jalala Talabaniego (Patriotycznej Unii Kurdystanu) z partią Massuda Barzaniego (Demokratycznej Partii Kurdystanu) w kwestii tworzenia wspólnego gabinetu stojącego na czele autonomii Kurdystanu. Bibliografia ma czytelny podział. Pomocny w poszukiwaniu konkretnych informacji w publikacji jest zamieszczony na końcu książki indeks nazwisk i nazw geograficznych.

W pierwszym rozdziale zatytulowanym Podstawowe informacje o Kurdach i Kurdystanie przedstawione zostały najistotniejsze dane, takie jak: położenie geograficzne (zawierające liczne mapy), bogactwa naturalne, historię pochodzenia ludów kurdyjskich, demograficzne wskaźniki, podziały językowe oraz kwestie religijne. W części poświęconej symbolom narodowym Autor w lapidarny sposób odwołał się do flagi Kurdystanu i symboliki w niej zawartej, narodowego święta Newroz (Nowy Dzień) oraz hymnu Ey Reqib, który od powstania Republiki Mahabadzkiej funkcjonuje jako oficjalna pieśń narodowa.

Następne dwie części książki stanowią wprowadzenie do historii politycznego ruchu kurdyjskiego w Iraku, który zacząl funkcjonować po utworzeniu mandatu brytyjskiego na terenie Iraku. Wskazane zostały miejsce i czas powstania najistotniejszych organizacji. Opisane zostało powstanie i upadek Republiki Mahabadu oraz relacje kurdyjsko-baasistowskie. Krakowski kulturoznawca przez analizę ewolucji ideologii i struktury BAAS stara się wyjaśnić historię polityczną oraz okoliczności podpisania manifestu marcowego, który miał stanowić obietnicę powstania kurdyjskiej autonomii. W sekcji dotyczącej formacji pozarządowych przedstawiono heterogeniczność społeczności kurdyjskich, które nie posiadały jednego programu narodowego, często nad politykę narodową stawiano interes plemienny czy prywatny. Przykład stanowi służba w prorządowych oddziałach wojskowych tzw. dżahszów, gdzie ludzie w zamian za żołd byli w stanie stopować kurdyjską działalność narodową (s. 79). Rozdział kończy analiza wojny iracko-irańskiej, masakry Al-Anfal przeprowadzonej na rozkaz „chemicznego Aliego” Hasana Al-Madżida oraz wojna w Zatoce Perskiej. Ciekawym rozwiązaniem zastosowanym w książce było wprowadzenie przez Autora kwestii międzynarodowej odpowiedzi na klęskę powstania Kurdów, gdzie została wyróżniona między innymi pozycja Turcji, ONZ czy Stanów Zjednoczonych Ameryki Północnej. Przywołane zostały istotne propozycje takich polityków jak ówczesnego premiera Wielkiej Brytanii Johna Majora (koncepcja safe haven), sekretarza stanu USA Jamesa Bakera oraz prezydenta George'a Busha.

Czwarty rozdział krakowski kurdolog poświęcil kwestii powstania autonomii w północnym Iraku. Istotnym jest wprowadzenie tabeli prezentującej wyniki wyborów do Kurdyjskiego Zgromadzenia, w którym zasiadło 105 deputowanych. Przedstawiono również genezę nowego aliansu PUK-DKP, na czele którego stanął w 1992 roku Fuad Massum. 
Ostatecznie udało się utworzyć nowy gabinet pod koniec września 1996 roku, na czele którego stanął Rosz Szawis, w jego skład nie wszedł żaden minister z PUK. Postuluje się, że dzięki wykorzystaniu środków z programu „Ropa za Żywność” stworzono stabilny budżet kurdyjskiej autonomii. O prosperity gospodarki zarządzanej przez Kurdów zdaniem K. Lalika stanowią nadwyżki zboża, które mogły być sprzedawane do Iranu i Turcji oraz pensje akademickie, które znacznie przewyższały te z Bagdadu (s. 118). Dziwić może fakt, że w rozdziale związanym $\mathrm{z}$ rozwojem autonomii północnoirackiej pojawia się wzmianka o delegalizacji PKK w Niemczech (s. 122), jednakże jest to istotny czynnik, który wpływał na politykę RFN wobec kwestii kurdyjskiej i w pewien sposób kształtuje ją po dziś dzień, co najwidoczniej zostało przeoczone.

Wojnę domową w Kurdystanie, która rozpoczęła się w 1994 roku, zakończyło, mimo prób podejmowanych przez François Mitteranda czy rząd turecki, podpisanie tak zwanego Układu Waszyngtońskiego 17 września 1998 roku. Autor Kurdystanu irackiego u progu $X X I$ wieku czyni z podpisania owego porozumienia istotną cezurę, która kształtowała relacje kurdyjskie oraz między Kurdami a rządami państw regionu. Jednakże dopiero wydarzenia na Bliskim Wschodzie, które miały miejsce po 11 września $2001 \mathrm{r}$. doprowadzily do zjednoczenia się dwóch dominujących kurdyjskich bloków politycznych w Iraku. Rolą Iranu było uzyskanie choćby częściowej kontroli nad rozwojem ruchu narodowowyzwoleńczego na terytorium własnym i w Iraku; ograniczenie wpływu USA i Turcji w regionie; wzmacnianie pozycji Kurdów w południowym Kurdystanie na rzecz osłabiania pozycji władz bagdadzkich (s. 140). Natomiast USA starały się w czasie operacji Providing Comfort, jak również Northern Watch sprowadzać politykę BAAS do roli marionetki, czego przykład stanowi zmiana strefy zakazu lotów z 32 na 33 równoleżnik w 1996 roku (s. 154).

Piąty rozdział zatytułowany: Kwestia kurdyjska w Iraku po obaleniu rezimu Saddama Husajna stanowi opis sytuacji politycznej od momentu rozpoczęcia misji wojsk koalicyjnych „Operacja iracka wolność” do ukonstytuowania się władz w 2005 roku oraz budowy stabilizacji polityczno-gospodarczej w Kurdystanie. Ten burzliwy w historii Iraku okres został podzielony na cztery części. W pierwszej opisane zostały ostateczne zmagania się władz partii BAAS z siłami koalicyjnym oraz problemami wewnętrznymi. Kolejno zaprezentowany został proces tworzenia się władz tymczasowych, po obaleniu rządów baasistowskich nad Tygrysem i Eufratem. Krzysztof Lalik wskazał na istotę tymczasowego prawa administracyjnego tzw. TAL, które gwarantowało utworzenie trójreprezntatywnej władzy sunnicko-szyicko-kurdyjskiej. Przedstawiono również wyniki referendum przeprowadzonego w trzech pólnocnych okręgach, znajdujących się pod zwierzchnictwem KRG, w których to ponad dziewięćdziesiąt proc. ludności opowiedziało się za pełną niepodległością Autonomii. DPK jednakże nie wykorzystała owych wyników dla celów secesyjnych obawiając się reakcji organizacji międzynarodowych, jak również samych USA -zdaniem K. Lalika. W trzeciej części zaprezentowano tak zwane ,stałe rozwiązania”. Wyjściowym momentem były wybory przeprowadzone pod koniec stycznia 2005 roku, które Autor analizuje w ciekawy sposób, zestawiając całość wyników w formie tabelarycznej. Z powodu licznych prób wetowania projektu ustawy zasadniczej ponowne wybory przeprowadzono w grudniu. Nie doprowadzily one do znaczących przetasowań na scenie politycznej Iraku. W ostatniej sekcji rozdziału wskazano najważniejsze czynniki wpływające na strukturę władzy, która ukonstytuowała się po wyborach przeprowadzonych równolegle do wyborów ogólnopaństwowych 31 stycznia 2005 r. Autor skorzystał z wyników opracowanych przez Niezależną Komisję Wyborczą Iraku. Wskazane zostały również relacje polsko-kurdyjskie, które od 2005 roku nabrały charakteru oficjalnego - dyplomatycznego. 
W podsumowaniu Krzysztof Lalik wskazal, iż wciąż problemem jest marginalizowanie relacji z Kurdami przez Stany Zjednoczone na rzecz budowania stabilnych relacji z Bagdadem.

Rozdział szósty jest analizą sytuacji gospodarczo-społecznej, gdzie wiele uwagi poświęcono ropie naftowej i możliwościom jej obrotu. Drugim tematem są tak zwane ,tereny sporne", czyli w przypadku kurdyjskim przede wszystkim kwestia Kirkuku, która do dnia dzisiejszego nie znalazła swego prawnego rozstrzygnięcia. Nawet w przypadku długo odwlekanego referendum, jego wyniki mogą być kontestowane, a co za tym idzie - niewiążące władzy w Bagdadzie. Misja ONZ-owska dla Iraku (UNAMI) zaproponowała cztery rozwiązania dla okręgu Kirkuk, żadne z nich nie zakłada podziału owego obszaru, jednakże według Autora jeden zakłada współzarządzanie nim przez Irbil oraz Bagdad (s. 252). Niezmiernie ciekawą kwestią, którą Autor przedstawił w lapidarny sposób, rzadko prezentowaną w książkach o tematyce kurdyjskiej jest problem turkmeński w Iraku. W dalszej części rozdziału pojawia się kwestia chrześcijan irackich, którzy od wieków zamieszkują również Południowy Kurdystan. W opracowaniu tej części zabrakło pozycji polskojęzycznych autorstwa Michaela Abdalli, który jako przedstawiciel chrześcijan bliskowschodnich, wiele uwagi poświęcił tematyce asyryjskiej w swoich artykułach ${ }^{1}$. Cały rozdział kończy kwestia osądzenia sześciu z siedmiu oskarżonych wojskowych i dygnitarzy w sprawie operacji Al-Anfal².

W rozdziale siódmym przeanalizowane zostały relacje między Regionem Kurdystanu a: Stanami Zjednoczonymi, Turcją, Iranem oraz Syrią. Najwięcej miejsca Autor poświęcił relacjom kurdyjsko-tureckim, następnie transatlantyckim. Niespełna stronę poświęcono stosunkom syryjsko-kurdyjskim. Autor zwraca uwagę, iż z jednej strony Ankara stanowi dla Regionu Kurdystanu Irackiego (RKI) największe zagrożenie wśród państw sąsiadujących, które poprzez kampanie militarne na przełomie 2007/2008 roku wielokrotnie naruszało granice za przyzwoleniem USA. Krakowski badacz wskazuje również, że nie przypadkowo wybrano datę lądowej ofensywy skierowanej przeciw partyzantom PKK na 22 lutego 2008 roku. Pięć dni wcześniej ogłosiło niepodległość Kosowo. Turcja rzekomo obawiając się secesji kurdyjskiej przeprowadziła interwencję jeszcze w lutym (s. 305).

Rozważaniom na temat alternatywy RKI wobec dalszej autonomii poświęca ostatni rozdział swojej książi Autor Kurdystanu irackiego u progu XXI wieku. Wprowadzenie do tej części publikacji stanowi argumentacja nt. stabilnej pozycji aparatu władzy w regionie Kurdystanu oraz skuteczności służb bezpieczeństwa. Zabrakło w tym miejscu danych empirycznych, z których można byłoby wyprowadzić takie wnioski. Jednak poziom zagrożenia wytworzony przez politykę zagraniczną i bezpieczeństwa Turcji wobec Kurdystanu Południowego stanowi wciąż jeden z najistotniejszych elementów budowania stabilności wewnętrznej w regionie.

Autor postuluje również, że stabilność gospodarcza, nie może być osiagnięta w pełni bez przyłączenia Kirkuk do RKI. Kwestia roponośnego obszaru w północnym Iraku zdaje

1 Por. M. Abdalla, O chrześcijaństwie asyryjskim wśród Arabów przed islamem. Zarys problematyki, w: Irak wczoraj i dzis. Wybrane aspekty wewnętrzne i międzynarodowe, red. S. Wojciechowski, Poznań 2005; idem, Trudne trwanie chrześcrjan Bliskiego Wschodu, w: Spory-konflikty zbrojne - terroryzm: dysfunkcjonalne czynniki wspólczesnych stosunków międzynarodowych, red. W. Malendowski, Poznań 2006.

2 Ostateczne wykonanie wyroku śmierci Aliego Hasana Al-Madżida miało miejsce 25 stycznia 2010 roku, co nastappiło tydzień po zasądzeniu winny za masakrę w Halabdży w 1988 roku. Por. M. Tran, Iraq executes Chemical Ali, „The Guardian” z 25 I 2010. 
się być postponowana, gdyż ani Prezydent Federacji, ani obecny premier Nouri Al-Maliki nie są w stanie zaproponować rozwiązania, które w sposób definitywny i pokojowy rozwiązałoby ten palący problem. Przytoczone zostało również rozwiązanie wykreowane przez International Crisis Group, w którym postuluje się wprowadzenie proporcjonalnego podziału w administracji prowincji Kirkuku według formuly: 32-32-24-4 (Kurdowie, Arabowie, Turkmeni i chrześcijanie), odrzucające jednocześnie możliwość przeprowadzenia referendum w regionie. Autor wskazuje, iż przyjęte rozwiązanie federalne stanowi asumpt do kształtowania stabilności w tym rejonie świata, gdyż nie tylko Kurdowie stanowią czynnik potencjalnie separatystyczny, ale i szyici zamieszkujący południowo-wschodnie tereny przygraniczne. Przyszłość Iraku uzależniona została od polityki USA wobec tegoż państwa, jak również od funkcjonowania ,frontu antykurdyjskiego" uosabiającego politykę Turcji, Syrii oraz Iranu wobec Kurdystanu irackiego. Badacz kwestii kurdyjskich konstatuje „szanse powstania niepodległego Kurdystanu są niewielkie” (s. 329). Jednak postępująca szyityzacja na pohudniu państwa oraz powstanie nowego kraju, w którym dominowałby szariat, mogłyby zdaniem Autora przyczynić się do wsparcia przez USA niepodległości Kurdystanu, jako bufora bliskowschodniego. Konkluzją pozostawia kwestię niepodległości Kurdów jako wciąż otwartą jednak bliżej nie określoną w czasie.

W recenzowanej książce możemy doszukać się kilku powtórzeń. Wiele spośród omówionych w pierwszych siedmiu rozdziałach treści pojawiło się w podsumowaniu, które stanowi ostatni rozdział pracy, nie wnosząc jednak niczego istotnego do rozważań nad postawiony w tytule rozdziału pytaniem. Autor nie uniknąl również błędów w pisowni decydując się na używanie nazwy angielskiej dla stolicy RKI „Erbil’”. Według standardów nazw geograficznych opracowanych przez Komisję Standardów Nazw Geograficznych przy Glównym Geodecie Kraju, rekomendowana jest pisownia „Irbil”3. Rola państw Unii Europejskiej została zmarginalizowana na rzecz hegemonicznej pozycji USA i Turcji w regionie. Niemniej trud pracy włożony przez Krzysztofa Lalika w opracowanie ogromu materiałów (zwłaszcza prasowych) należy ocenić jako bardzo istotny. Ważnym jest również, że recenzowana publikacja wpisuje się w niszę, gdzie obok książki autorstwa Marii Giedz ${ }^{4}$, dostarcza polskiemu czytelnikowi aktualnych informacji na temat problemu kurdyjskiego.

Błażej GRYGO

Uniwersytet im. Adama Mickiewicza, Poznań

\section{Marcin Nowacki, Prawne aspekty bezpieczeństwa energetycznego w Unii Europejskiej, Wydawnictwo Oficyna Wolters Kluwer Business, Warszawa 2010, ss. 472.}

Treść książki podzielona jest na sześć rozdziałów, a każdy z nich składa się z kilku lub kilkunastu podrozdziałów. Objętość poszczególnych rozdziałów jest podobna. W książce zawarto wykaz skrótów i nazw wszystkich organizacji międzynarodowych i instytucji unijnych, które powstawały na przestrzeni lat w celu tworzenia polityki energetycznej na świe-

Nazewnictwo geograficzne świata. Zeszyt 2. Bliski Wschód, GUGiK, Warszawa 2004, s. 40-41.

M. Giedz, Kurdystan. Bez miejsca na mapie, Pelplin 2010. 